\title{
The Development of the Classical Observatory: From a Functional Shelter for the Telescope to the Temple of Science
}

\section{Tapio Markkanen}

University of Helsinki

Haltijatontuntie $4 \mathrm{~A} 4$,

Espoo 02200, Finland

E-mail: tapio.markkanen@helsinki.fi

\begin{abstract}
At the end of the $18^{\text {th }}$ century and at the beginning of the $19^{\text {th }}$ century, observatory buildings underwent a change, because astronomical tools of observation had transformed from light portable equipment into permanently mounted accurate instruments. For positional astronomy, observations were mainly carried out in the meridian or in the prime vertical. A new type of telescope, the equatorially mounted refractor was adopted for the observation of objects such as planets, comets and double stars. The new instruments and methods of observation also required new approaches to observatory design. The new research needs began to determine the exterior, structure and functions of the observatory building. At the beginning of the $19^{\text {th }}$ century, new standards of observatory planning were developed for the construction of the new observatories of Tartu, Helsinki and Pulkovo. Over many decades, the adopted design principles guided the construction and architecture of avant-garde observatories around the world. They also provided for the archetype of the observatory as a universal emblem for science well into the $20^{\text {th }}$ century. The article discusses the development stages of these design principles and their global impacts.
\end{abstract}

Keywords: astronomical instruments, history of astronomy, methods of observation, observatories 


\section{Changes in astronomical methods of observation towards the end of the $18^{\text {th }}$ century}

Until the late $18^{\text {th }}$ century, astronomical observations were mainly carried out in order to determine stellar positions for mapping and cataloguing purposes, and for timekeeping. Astronomical observing equipment was of two main types, either light portable instruments or mural quadrants in cases where higher accuracy was needed. Mural quadrants had been in use since antiquity, the most famous of them perhaps the Ulugh Beg's giant underground quadrant in Samarkand, Uzbekistan, and the large quadrant of Tycho Brahe at his observatory on the island of Hven at the entrance to the Baltic Sea. Well-preserved examples of a mural quadrant can be seen, for example, at the Royal Observatory Greenwich, Landesmuseum für Technik und Arbeit in Mannheim, Germany, and at the old observatory (the White Hall) connected with the Vilnius University Library. The observation of compact objects, such as double stars or planets, required the building of increasingly bigger reflectors. The largest of them, especially the 40foot reflector of William Herschel and Lord Rosse's "Leviathan of Parsonstown" at the Birr Castle in Ireland, were awkwardly pointed towards their objects by pulleys and ropes and were not appropriate for observations of high accuracy (cf. King, 1955 passim; Herrmann, 1984, p. 157ff).

With the development of celestial mechanics the requirements for accuracy in positional astronomy increased and new branches of astronomy grew in importance. The physical nature of celestial bodies, such as planets and double stars, and the structure of the stellar system shifted to the focus of interest. Towards the end of the $18^{\text {th }}$ century, two new types of instruments entered the astronomical scene- the meridian circle and the equatorially mounted refractor. Some specialized instruments, such as the repeating circle, were popular during a few decades. Efficient use of the latter facilitated the introduction of new elements to observatory architecture, especially the revolving dome, which was later mainly used for the equatorial refractor. To shelter the repeating circles, revolving domes were built by Johann Tobias Mayer in Göttingen in the late $18^{\text {th }}$ century (Benzenberg, 1813, pp. 147-158) and by Franz Xavier von Zach at the Seeberg Observatory in Gotha in 1790 (Brosche 1988, pp. 173-204). A revolving dome was also completed at the Dunsink Observatory near Dublin in 1785. When the observatory of the University of Tartu was completed in 1810 on the initiative of the Rector of the university, Georg Frédéric Parrot, professors Johan(n) Wilhelm Pfaff and Johann Gottfried Huth, and the architect Johan(n) 


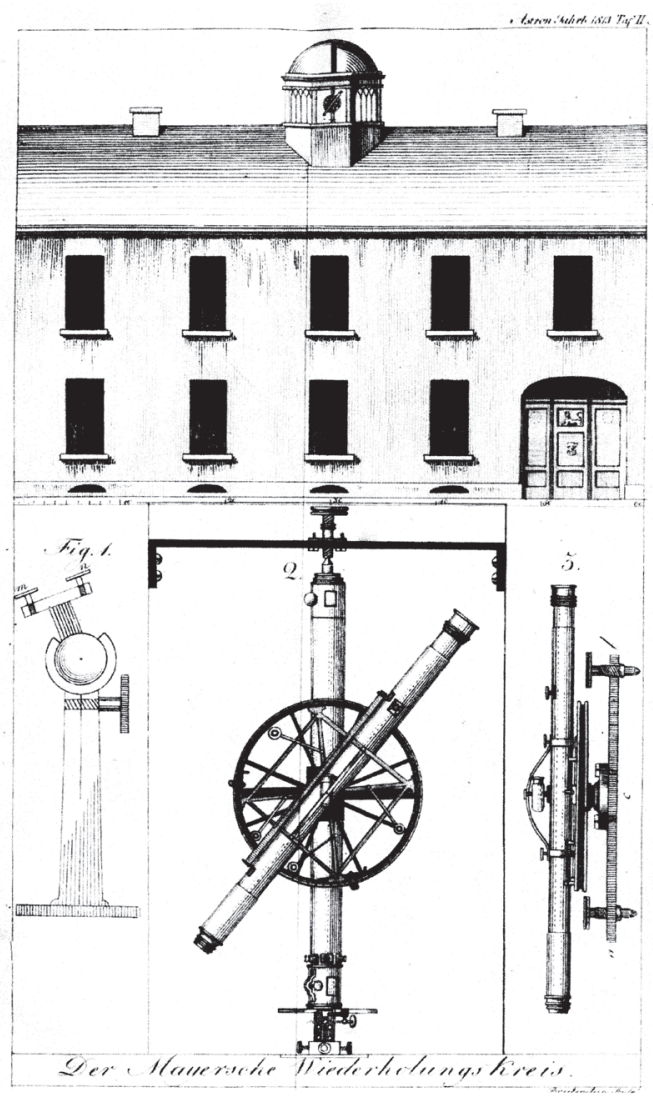

Figure 1. The small dome on top of the Göttingen Observatory (Benzenberg, 1813, Tafel II).

Wilhelm Krause, it was also given a small hemispherical dome (Tursk \& Leppik, 2011, p. 32).

Around the Baltic Sea, several new observatories were founded within a few decades at the end of the $18^{\text {th }}$ and at the beginning of the $19^{\text {th }}$ century. Changes in instruments and observation methods are clearly reflected in the design principles and architectural solutions of these institutions. The new instruments and observing techniques also established new standards and requirements for the design of buildings which could provide shelter from the weather and stable foundation for the sensitive equipment.

The Observatory of the Royal Swedish Academy of Sciences was built in Stockholm in 1753. It carried further the idea of observations being made either with small instruments that could be taken outside when the sky was clear or observing through open windows with telescopes standing in a big hall. In 1813, the same idea was put into practice at the Königsberg Observatory under the lead of Friedrich Wilhelm Bessel.

Finland was part of Sweden until 1809, when it became an autonomous grand duchy of the Russian Empire. The University of Turku had been founded in 1640, with astronomy in its curriculum since the very beginning. From 1750 on, Finnish astronomers participated in international frontline research programmes. As a result of the efforts of Gustav Gabriel Hällström, professor of physics, an observatory was built in Turku in 1819. The architect was Carl Ludwig Engel from Prussia. In planning the new observatory, Engel and Hällström closely followed 


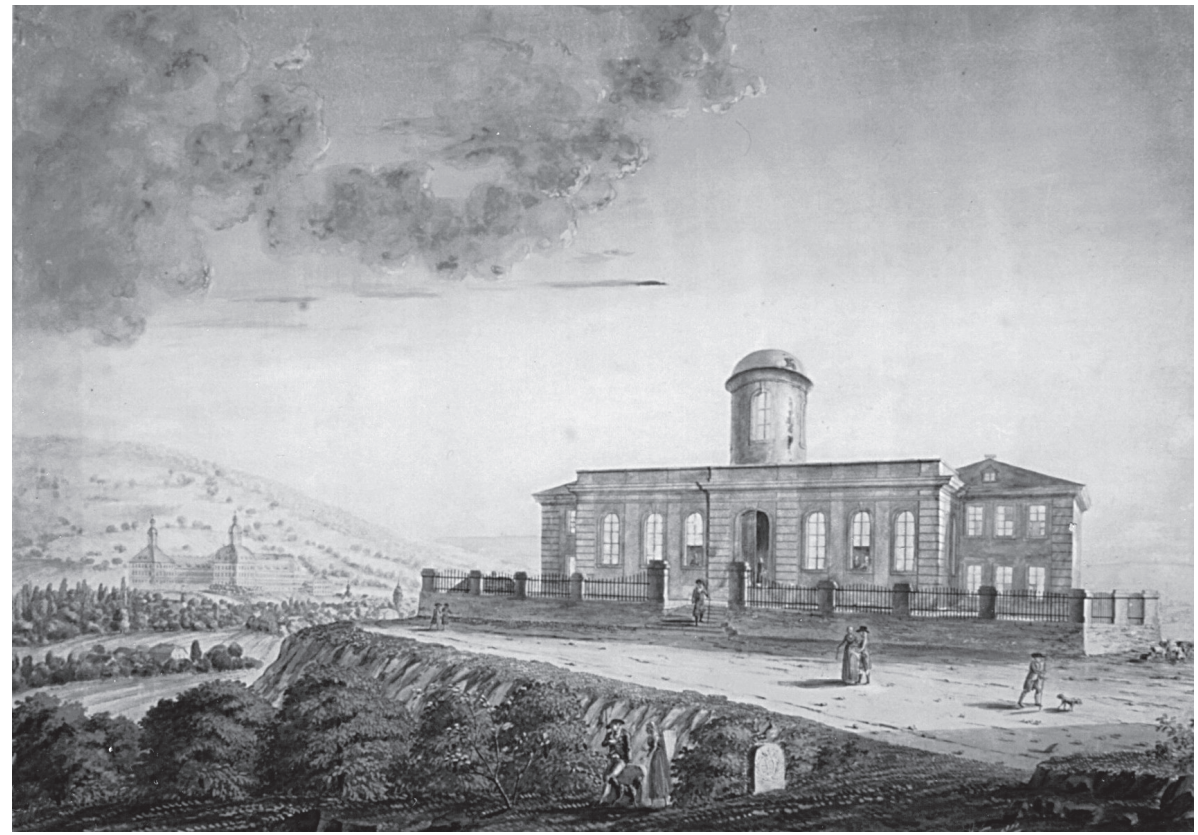

Figure 2. The dome of the Seeberg Observatory, Gotha in c. 1800 (Seeberg Observatory, n.d.).

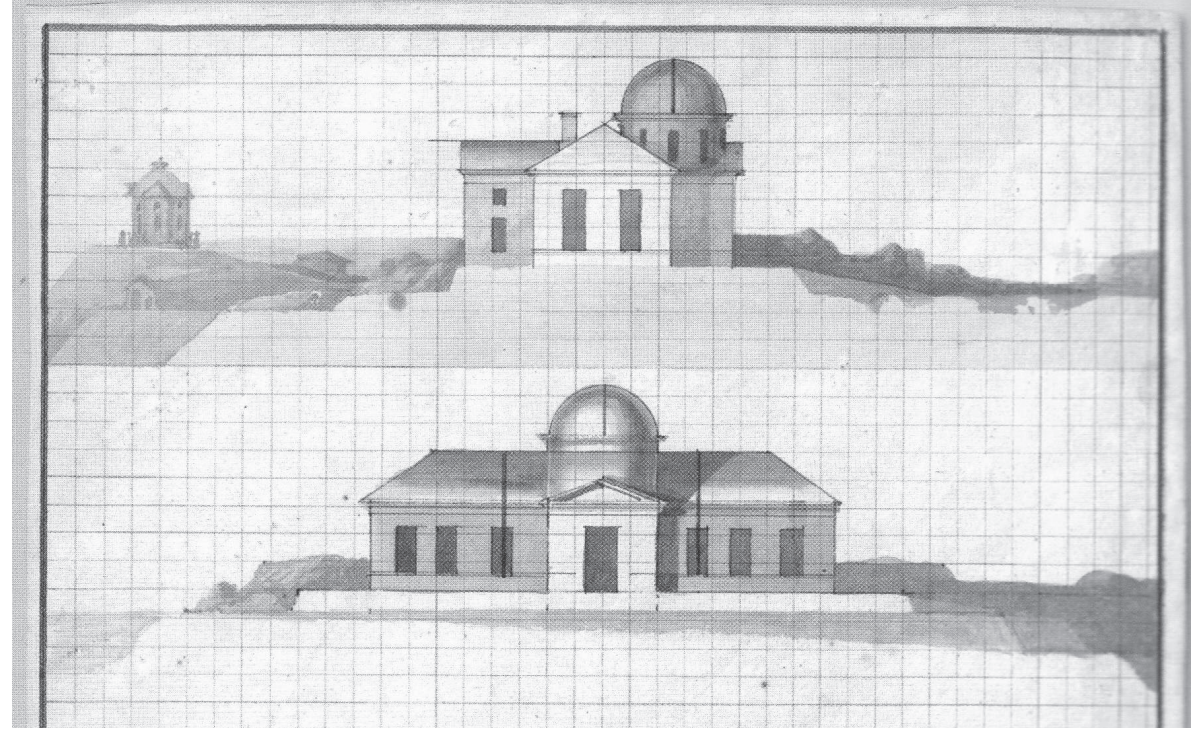

Figure 3. Tartu Observatory in 1810 (Tursk \& Leppik, 2011, p. 32). 
the Stockholm model, which had already become outdated by then. While at an early phase of planning the Turku Observatory, Hällström was fond of the classical mural quadrant, he later changed his mind in favor of the more modern meridian circle. Among the instruments that were ordered for the Turku Observatory from Utzschneider and Fraunhofer in 1818 was also an equatorial refractor with objective lens $176 \mathrm{~mm}$ in diameter and with a $2700 \mathrm{~mm}$ focal length. No appropriate dome was planned for it, however (Lehti \& Markkanen, 2011, pp. 60-107).

\section{Building on experiences}

In these years, the instruments and methods of observation changed rapidly. In Tartu, Professor Struve acquired a 9-inch refractor from Fraunhofer. It arrived in 1824 and was immediately taken into use in a revolving dome, completely rebuilt according to the design by Parrot (Struve, 1825). In the same decade, Wilhelm Bessel added

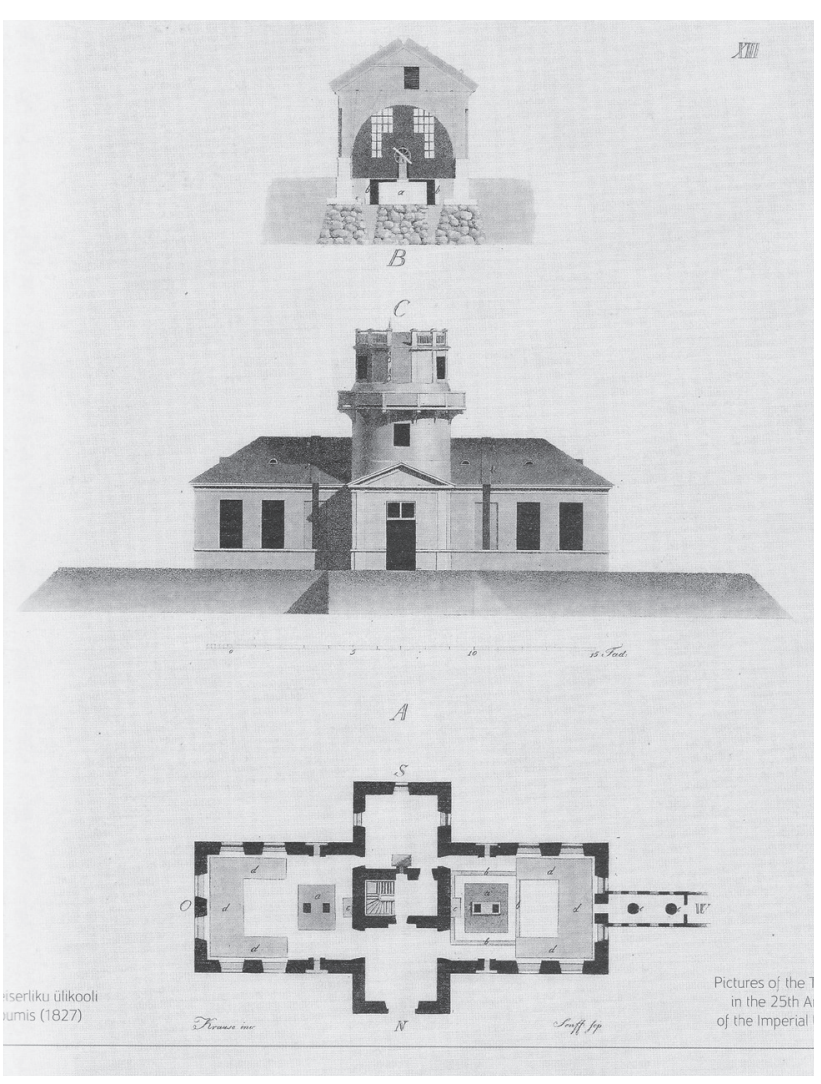

a revolving dome to the Königsberg Observatory for the $157-\mathrm{mm}$ Utzschneider and Fraunhofer heliometer.

Turku had been the capital of Finland for centuries. In 1812, however, Helsinki was made capital. After Turku was ravished by fire in September 1827 , the university was also transferred to Helsinki.

Figure 4. Tartu Observatory and its new revolving dome for the Fraunhofer refractor (Tursk \& Leppik, 2011, p. 33). 


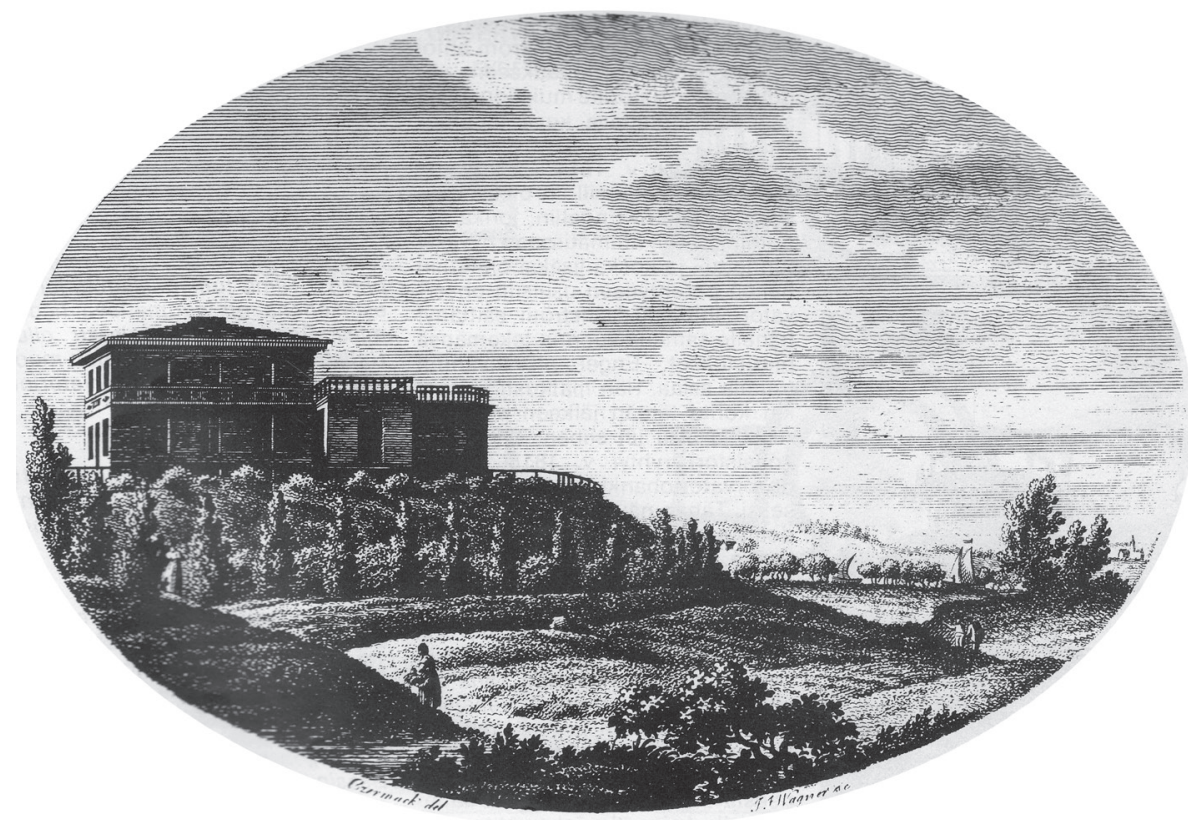

Figure 5. The Königsberg Observatory in its original form in 1813 (Bessel, 1815, p. i).

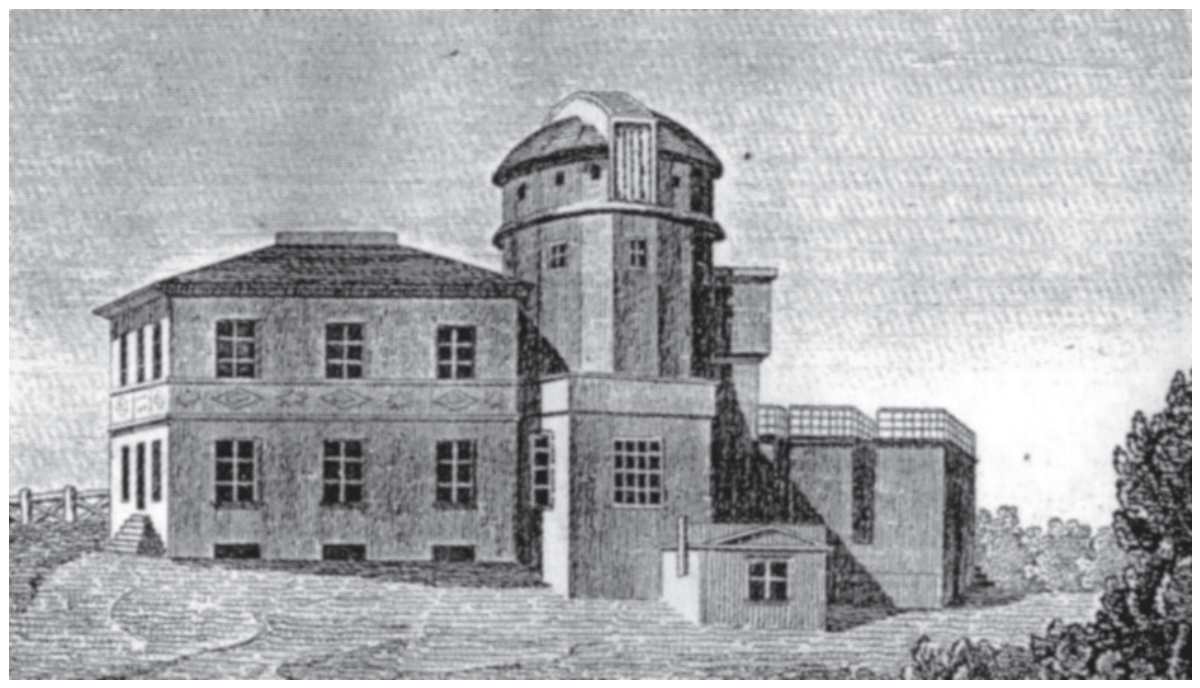

Figure 6. The Königsberg Observatory and the dome built for the heliometer in 1829 (Steinicke, n.d.). 


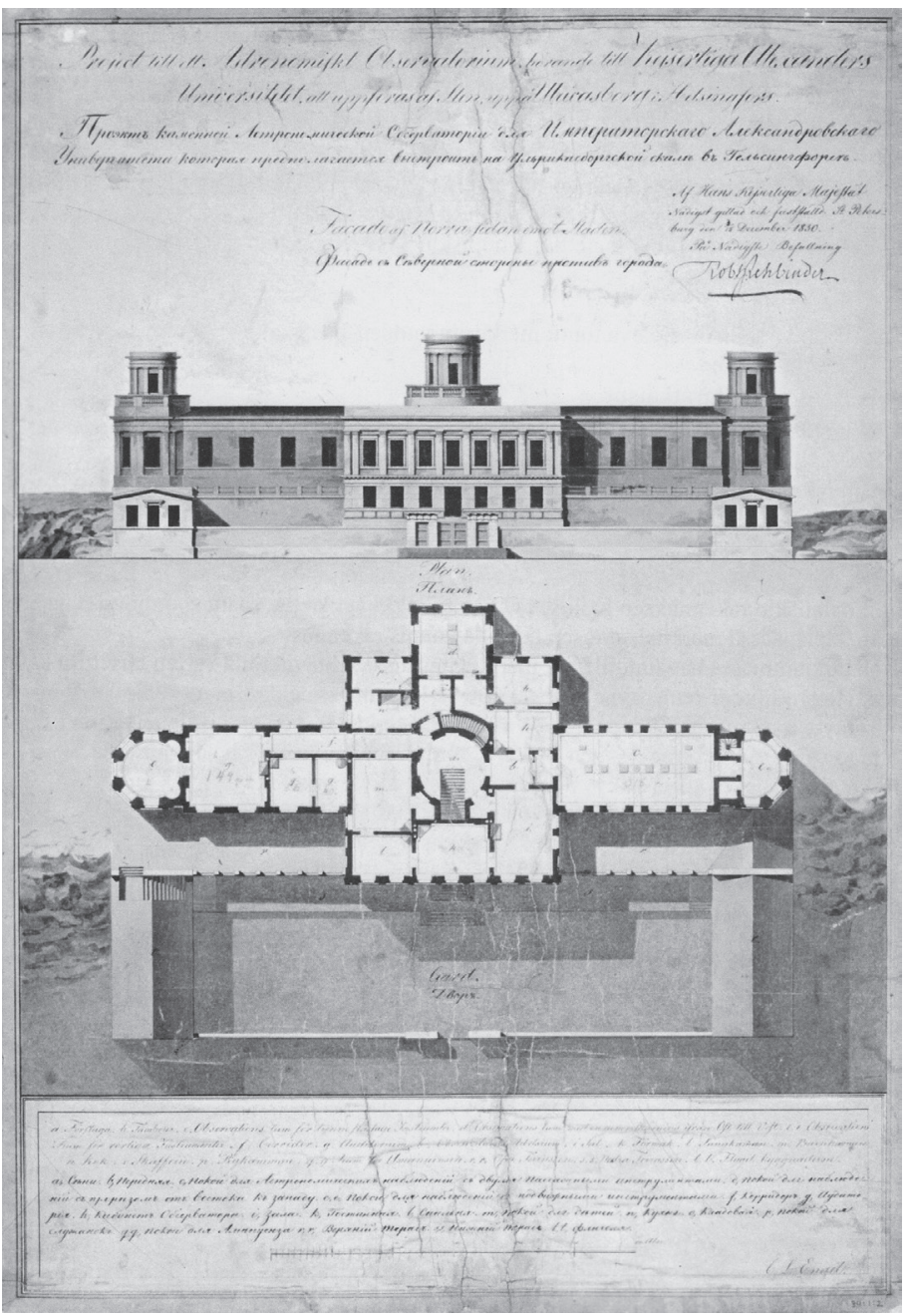

Figure 7.

Helsinki

Observatory, northern façade towards the city centre. The floor plan is oriented with south at the top. Architectural drawing by C. L. Engel from 1829. Image by Helsinki University Museum.

Friedrich Wilhelm Argelander, a student of Bessel at the University of Königsberg, had been active as astronomer at the University of Turku since 1823 and was assigned the task to build an observatory in the new capital. The architect Carl Ludvig Engel joined Argelander and as a result of this cooperation the university's new observatory was erected on Tähtitorninmäki Hill in 1834. Located on the exposed hill, the observatory was overlooking the entire city, so Engel designed it as an "embellishment for the city". Engel also designed several monumental buildings in the new capital-the Helsinki Cathedral, the Government Palace and most important buildings of the Helsinki University. Argelander was an experienced astronomer, familiar with state-of-the-art solutions and he established 


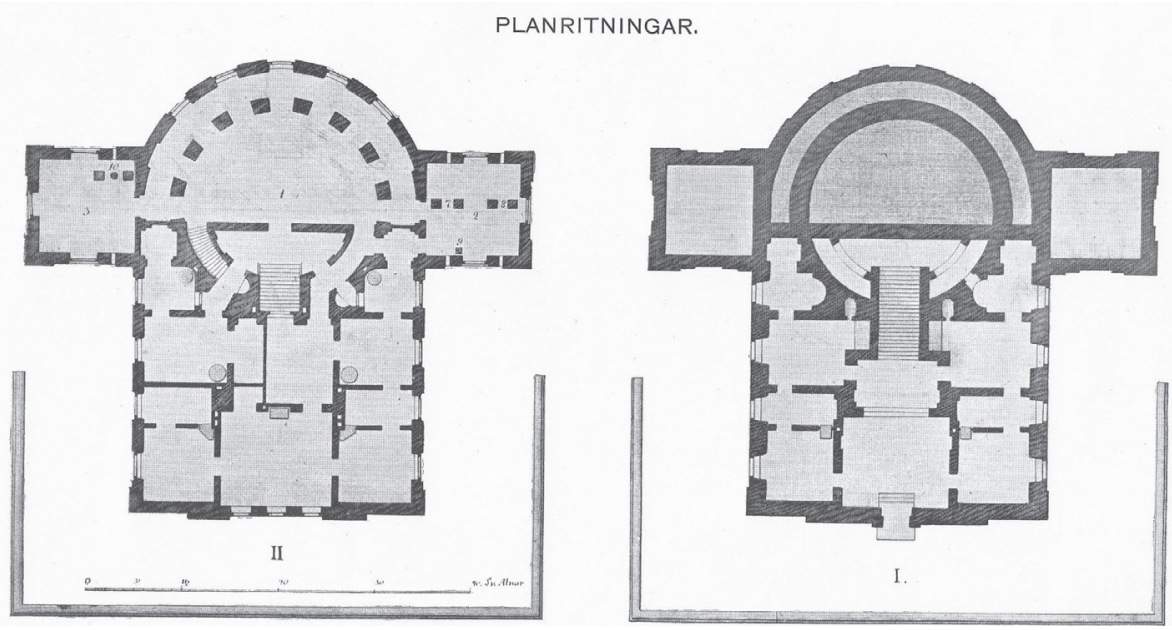

Figure 8. Floor plans for the Turku observatory by Engel, 1817. No massive foundations for the instruments were provided (Donner, 1910, p. 41).

the functional standards of the observatory design. Engel was a skilful architect, capable of actualizing these high ambitions. Many innovative solutions were used during the planning and building of the Helsinki Observatory.

The meridian room of the Helsinki Observatory offered facilities for three instruments used for determining the precise position of stars. Also, three towers with revolving cupolas were erected to accommodate telescopes that could be pointed in all directions of the sky. Engel was the first in the history of observatory planning to use three rotating observation towers as central architectonic elements. The massive foundations of the instruments were laid on bedrock and sheltered with surrounding partition walls so that no tremor would be transmitted from the structures of the building to the instruments. Moreover, the partition walls delayed any changes in temperature that would impede observations. The building also housed a library, teaching facilities and living quarters.

The innovations were not limited to the building's exterior design only. The development of underground foundations is also seen in observatories that were built within a few decades. In fact, the Observatory of Turku (built in 1819 after the Stockholm model) had no proper massive foundations for the permanently mounted instruments of high accuracy.

In the Tartu Observatory, massive and stable foundations were provided for the heavy meridian instruments. An underground partition wall was also constructed 
under the western meridian room in order to bring the floor closer to the instrument pillars (see Fig. 3). In Helsinki, the partition walls were made very thick in order to delay the temperature change under the observation facilities and thus improve their stability and accuracy during observations (Fig. 9).

In 1833, Nicholas I, Emperor of Russia decided to establish a new main observatory close to St Petersburg and invited Struve, head of the Tartu University Observatory, to oversee the project. Struve knew that the requirements of the latest observation technology had been ingeniously met in the design and construction of the new Helsinki Observatory. He thus asked Carl Engel, the architect of the Helsinki Observatory, to send his designs to serve as reference material for the new Russian observatory. In 1833, Engel sent Struve the requested plans of the Helsinki Observatory. Architect Alexander Brullov's plan for the Imperial Central Observatory of Pulkovo near St Petersburg followed the example of the Helsinki Observatory in terms of how the rotating towers and the meridian and prime vertical rooms were located and the overall structure of the building was designed, except on a larger scale. The functional principles of the underground

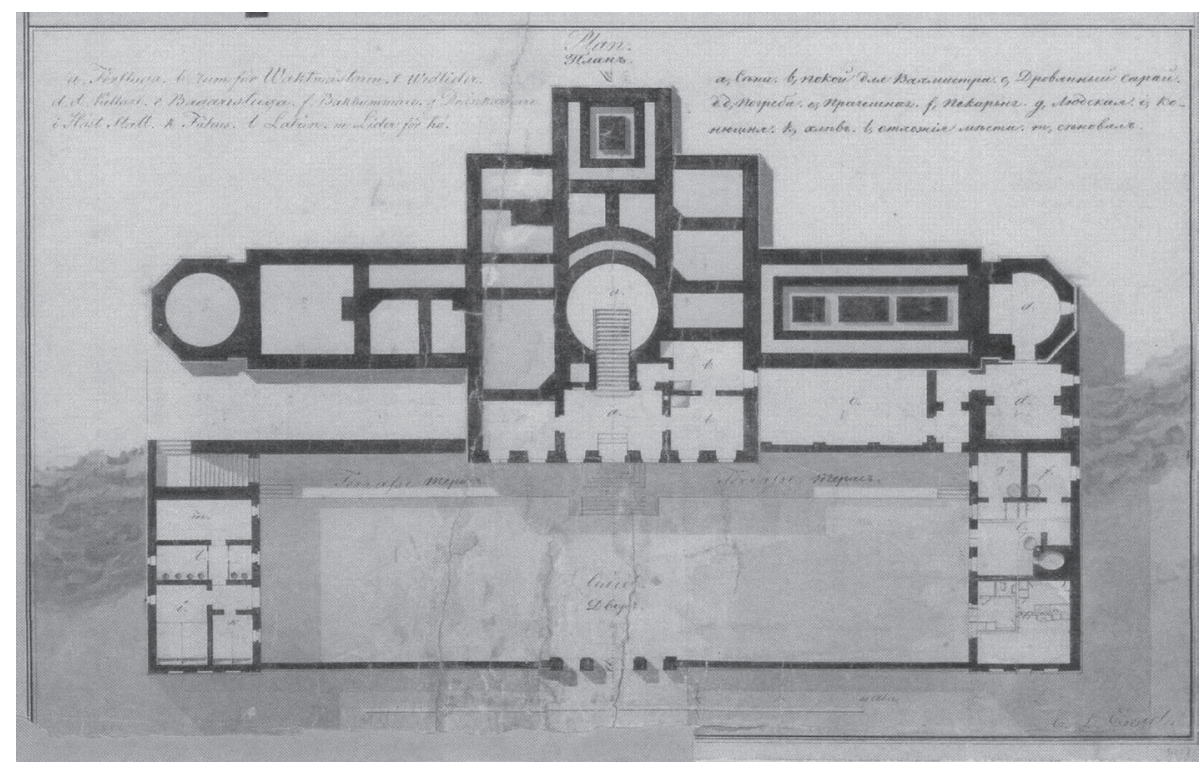

Figure 9. Underground structures of the Helsinki Observatory were made quite massive for improved structural stability and for slowing processes due to change of temperature. The pioneering solutions applied at the Helsinki Observatory were used in planning and constructing observatories around the world for decades. Image by Helsinki University Museum. 


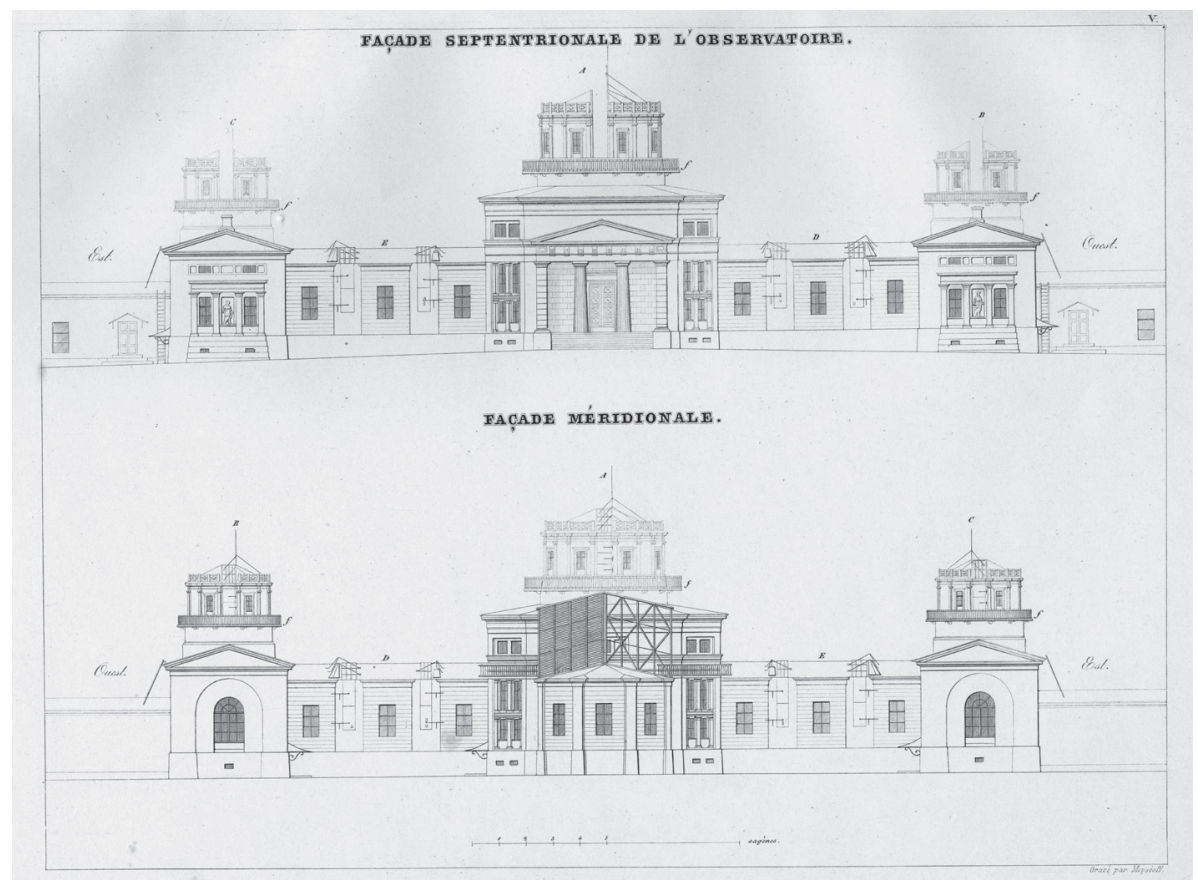

Figure 10. The Helsinki Observatory served as a model for the Pulkovo Central Observatory. The figure shows the northern façade of the Pulkovo Observatory. (Struve, 1845, Planche V). The observatory was destroyed during the Siege of Leningrad in 1941-1944, but was rebuilt after the war and the cylindrical turrets were replaced with hemispherical domes.

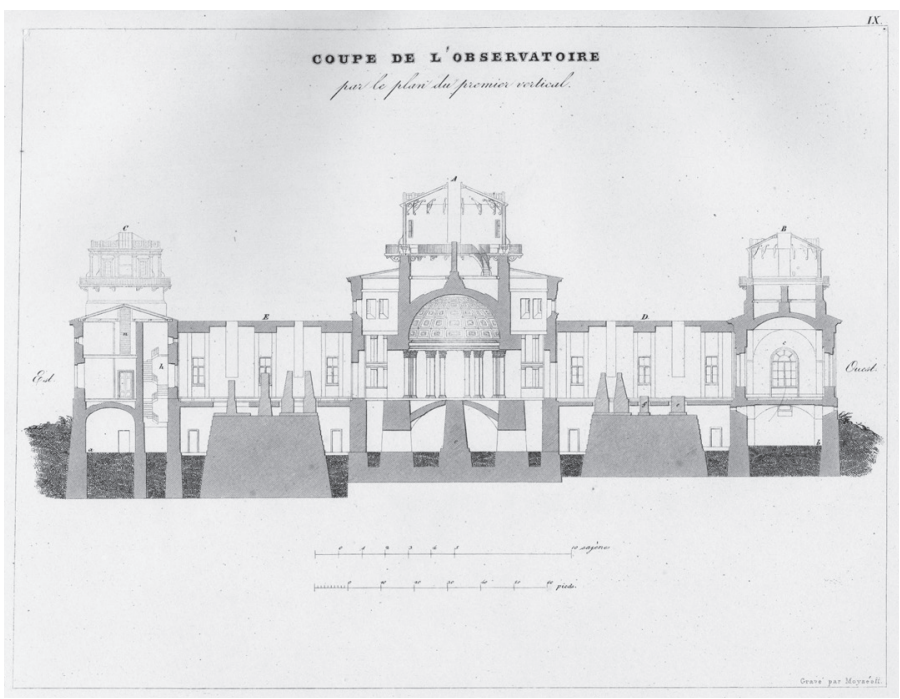

Figure 11. An eastwest cross-section of the construction drawing of the Pulkovo Observatory shows how the foundations of the instruments and observation rooms follow the Helsinki model (Struve, 1845, Planche IX). 
structures were also fully adopted in Pulkovo. The importance of having the floor of the observing spaces separated from the foundations of the instruments was clearly demonstrated by an incident that ruined a series of observations at Pulkovo in 1879 (Batten, 1988, p. 175).

\section{The functional observatory turned into a universal archetype of the temple of science}

Because of its scientific output, Pulkovo gained a reputation of being "the astronomical capital of the world" (B. A. Gould in Newcomb, 2010[1903], p. 309). For over half a century, the Pulkovo Observatory served as a model for observatories around the world, including, for instance, the observatories of Lisbon (built 1867), Potsdam (1874) and Berlin-Babelsberg (1913) (Müller, 1975; 1992).

Towards the end of the $19^{\text {th }}$ century, a new type of observatory was developed in response to the needs of the new science of astrophysics, especially spectroscopy and photometry. According to the new principles of design, new observatories were built on isolated mountaintops, far from city lights and smoke (Shane, 1972; Bowen, 1972).

The movement aimed at informing the general public about astronomy and the Universe spread in continental Europe at the end of the $19^{\text {th }}$ century. During the following decades, public observatories were built in big cities like Berlin, Vienna, Budapest, Antwerp and Zurich, especially for the urban population (Markkanen, in press, 2013). A monument to that ideology can be found on the other side of the world - the Griffith Observatory in Los Angeles. Griffith J. Griffith, an industrialist and philanthropist in Los Angeles, made his fortune in mining. On his visit to Mount Wilson Observatory (founded by George Ellery Hale near Los Angeles in 1904), Griffith gazed through the 60-inch reflector, the largest of its time, and was greatly impressed, reportedly saying, "If all mankind could look through that telescope, it would change the world!" In 1912, Griffith made a donation to the City of Los Angeles for a public observatory and science exhibit hall to be built on top of Mount Hollywood. The basic concept and draft design of the Griffith Observatory and Planetarium were created by the physicist Edward Kurth and Russel W. Porter, an artist and engineer and a central figure in American amateur astronomy. The building plans for the institution were made 


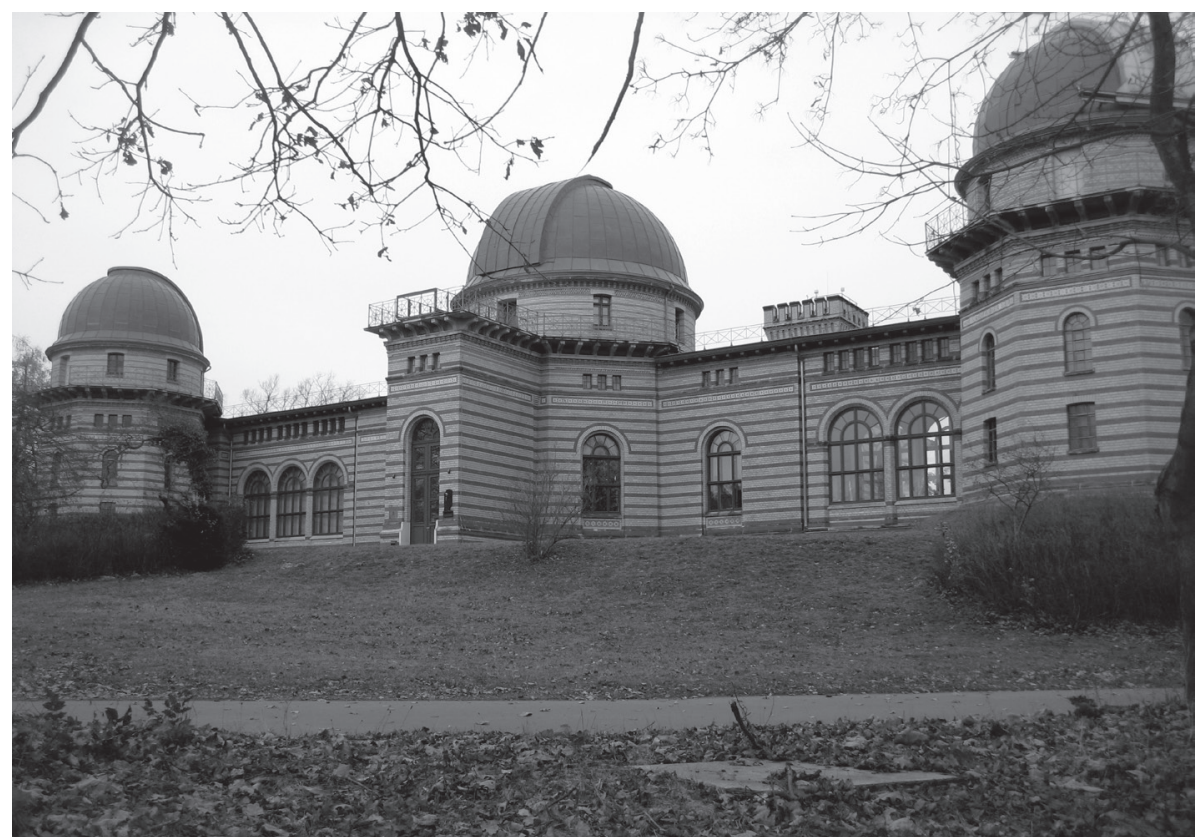

Figure 12. The Astrophysical Observatory Potsdam, built in 1874 on Telegrafenberg. Photo by T. Markkanen.

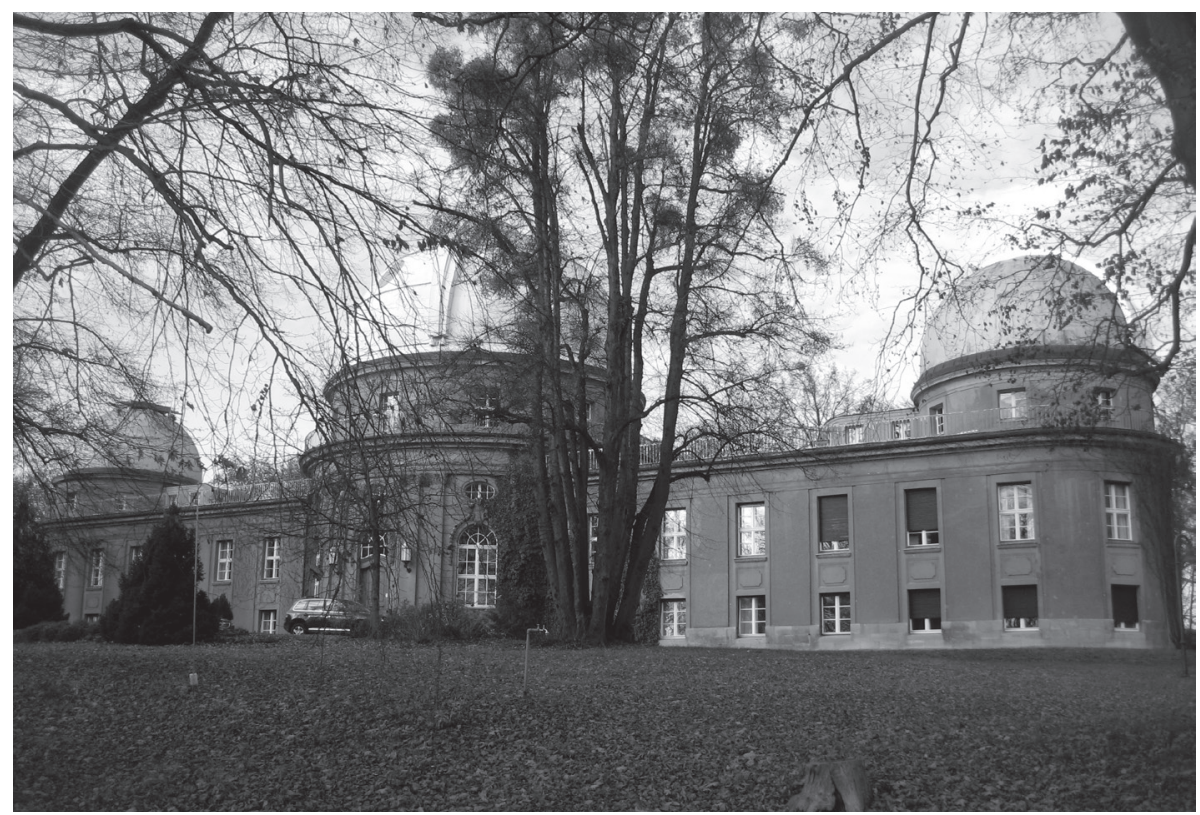

Figure 13. Berlin-Babelsberg Observatory was built in 1913. Photo by T. Markkanen. 


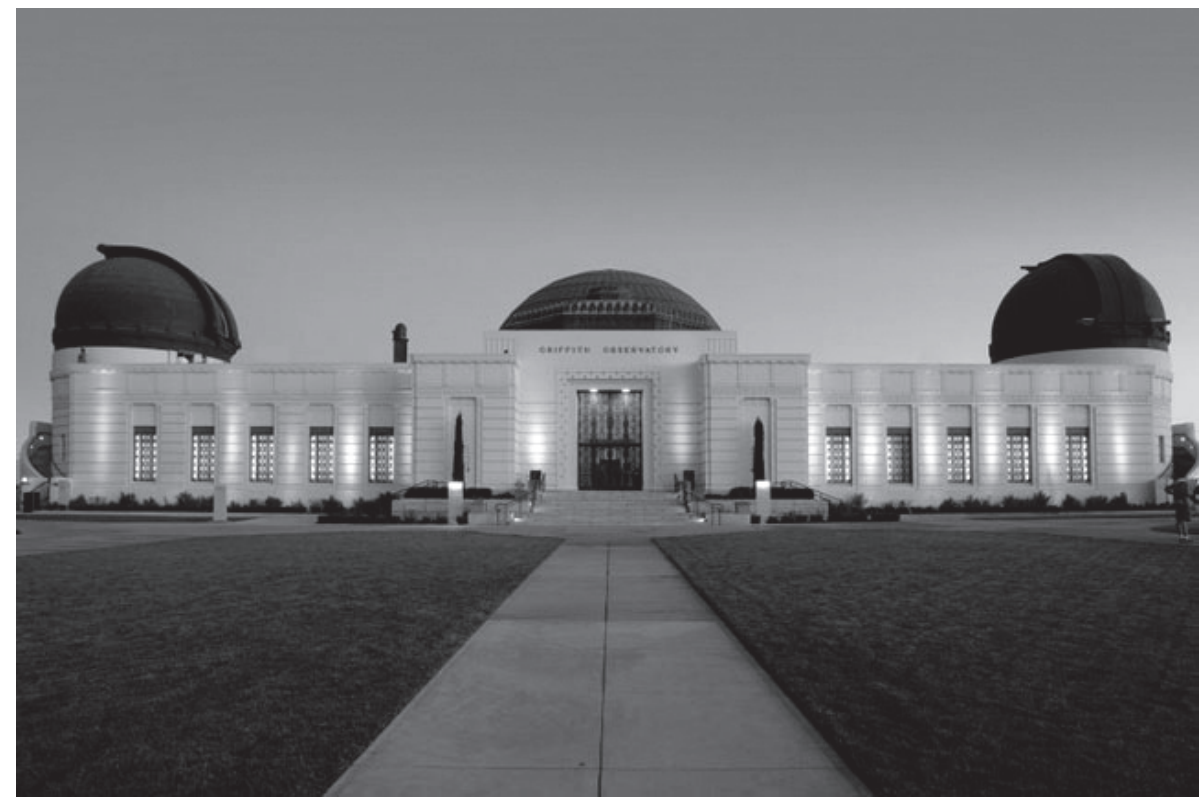

Figure 14. A functional observatory turned into an archetype of the temple of science: the Griffith Observatory in Los Angeles, established in 1935, is not a scientific institution but a public observatory and planetarium, providing the general public instruction in astronomy (Griffith Observatory, n.d.). The observatory is featured in many films: among others, in two major scenes of Nicholas Ray's Rebel Without a Cause, starring James Dean (1955).

by the architects John C. Austin and Frederic M. Ashley with Kurth and Porter as advisors (Griffith Observatory, n.d.). In 1935, the Griffith Observatory and its planetarium were completed in Los Angeles to educate the general public in astronomy. The facility was not intended for scientific observations, but its design followed the ideal of an observatory. The Griffith Observatory, which followed in the footsteps of the Tartu, Helsinki and Pulkovo observatories a century later, transformed the originally functional model of a research observatory into a universal temple of science (Markkanen, 2012, pp. 77-81). 


\section{References}

Batten, A. H. (1988), Resolute and Undertaking Characters: The Lives of Wilhelm and Otto Struve, Dordrecht \& Boston: D. Reidel Publishing Company. http://dx.doi.org/10.1007/978-94-009-2883-1

Benzenberg, J. F. (1813), 'Beschreibung und Abbildung des Mayerschen Wiederholungskreises,' Astronomisches Jahrbuch für das Jahr 1813, Berlin: J.E. Hitzig, pp. 147-157.

Bessel, Fr. W. (1815), Astronomische Beobachtungen auf der Königlichen UniversitätsSternwarte in Königsberg, Königsberg: bei F. Nicolovius.

Bowen, I. S. (1972), 'Astronomical Instrumentation in the Twentieth Century,' in H. Wright, J. N. Warnow \& C. Weiner (eds.) The Legacy of George Ellery Hale: Evolution of Astronomy and Scientific Institutions, in Pictures and Documents, Cambridge, MA: MIT Press.

Brosche, P. (1988), 'Franz Xaver von Zach und die Gründung der Seeberg-Sternwarte bei Gotha 1788,' in Jahrbuch der Coburger Landesstiftung, vol. 33, pp. 173-204.

Donner, A. S. (1910), Uppförandet af astronomiska observatorium i Åbo: en kulturhistoriskt märklig episod belyst genom en ny källa. Akademisk inbjudningsskrift, Helsingfors: [Lilius \& Hertzberg].

Griffith Observatory (n.d.), 'History,' Griffith Observatory [Image]. Retrieved from http://www.griffithobservatory.org/obshist.html [accessed August 2013]

Herrmann, D. B. (1984), The history of astronomy from Herschel to Hertzsprung, translated and revised by Kevin Krisciunas, Cambridge, MA: Cambridge University Press.

King, H. C. (1955), The History of the Telescope, High Wycombe, Bucks: Charles Griffin $\&$ Co.

Lehti, R. \& Markkanen, T. (2010), History of Astronomy in Finland 1828-1918, Sastamala: Societas Scientiarum Fennica.

Markkanen, T. (2012), Helsingin observatorio, Helsinki: Ursa. (in press, 2013), 'Maailman rakenne ja luonnonvoimat. Tähtitieteen ja fysiikan käännöskirjallisuus,' in O. Paloposki \& H. K. Riikonen (eds.) Suomennetun tietokirjallisuuden historia 1800-luvulta 2000-luvulle, Helsinki: Suomalaisen Kirjallisuuden Seura.

Müller, P. (1975), Sternwarten: Architektur und Geschichte der astronomischen Observatorien, Frankfurt am Main, Bern \& Las Vegas: Peter Lang.

(1992), Sternwarten in Bildern: Architektur und Geschichte der Sternwarten von den Anfängen bis ca. 1950, Berlin \& Heidelberg: Springer Verlag.

Newcomb, S. (2010[1903]), The Reminiscences of an Astronomer, Cambridge, MA: Cambridge University Press.

http://dx.doi.org/10.1017/CBO9780511709258 
Seeberg Observatory (n.d.), Sternwarte auf dem kleinen Seeberg bei Gotha [image]. Forschungs- und Landesbibliothek Gotha. Retrieved from http://en.wikipedia.org/ wiki/File:Seeberg_Sternwarte.jpg [accessed August 2013]

Shane, C.D. (1972), 'Astronomical Telescopes since 1890,' in H. Wright, J. N. Warnow \& C. Weiner (eds.) The Legacy of George Ellery Hale: Evolution of Astronomy and Scientific Institutions, in Pictures and Documents, Cambridge, MA: MIT Press.

Steinicke, W. (n.d.), Köningsberg Observatory and 6.2 Heliometer [Image]. Retrieved from http://www.klima-luft.de/steinicke/ngcic/persons/auwers.htm [accessed August 2013]

Struve, F. G. W. (1825), Beschreibung des auf der Sternwarte der Kaiserlichen Universität zu Dorpat befindlichen grossen Refractors von Fraunhofer, Dorpat: Gedruckt bei J. C. Schünmann.

_ (1845), Description de l'observatoire astronomique central de Poulkova, St. Pétersbourg: Imprimerie de l'Akadémie impériale des sciences.

Tursk, E. \& Leppik, L. (2011), 'A new observatory is built on Dome Hill', in L. Leppik (ed.) Tartu Tähetorn. Tartu Old Observatory, Tallinn: Aasta Raamat, pp. 32-33.

\section{Acknowledgements}

The author wishes to thank the anonymous referees for constructive comments and the editors for polishing the language of the article.

Professor Tapio Markkanen received his doctorate in 1977 from the University of Helsinki, Finland. He has taught Astronomy at that university and done research especially on Galactic structure, interstellar magnetic fields, and star formation. He has also published scholarly works on the history of science. Tapio Markkanen has also been active in developing science education and communication. In 1992-2006 he was Secretary General of the Finnish Council of University Rectors. In that capacity he was involved in developing national and European policies of research and higher education. As chair of the Finnish National Commission for UNESCO he also participates in the activities of that organization. 